\title{
ВЗАИМОСВЯЗЬ НЕОТЕКТОНИКИ И ГЕОДИНАМИКИ ДРЕВНИХ ПЛАТФОРМ НА ПРИ- МЕРЕ ОЛЕНЕКСКОГО ПОДНЯТИЯ И ЕГО ЮЖНОГО ОБРАМЛЕНИЯ
}

\section{Гордеев Н.А.}

Институт физики Земли им. О.Ю. Шмидта, Москва, gord@ifz.ru

В работе представлены результаты комплексного изучения Оленекского поднятия и его южного обрамления, в комплекс вошли геологические, структурно-геоморфологические и тектонофизические методы.

Территория исследования приурочена к Лено-Оленекскому междуречью на северо-востоке Восточно-Сибирской платформы. Наличие россыпных алмазов $[2 ; 3 ; 16 ; 17]$ и данных об Оленекском месторождении битумов [13], а также относительно трудная доступность района обусловили необходимость детального изучения новейшей тектоники района, т.к. на сегодняшний день на район исследований имеются лишь мелкомасштабные карты неотектоники [14; 4].

Основной целью работы было сопоставление новейших тектонических структур с новейшей и современной геодинамикой района. Установление взаимосвязи древних и новейших структур.

\section{Методы исследования}

Ряд полевых исследований заключался в изучении рельефа, в том числе морфологии речных долин, склонов водоразделов и др., исследовались коренные и четвертичные отложения, проводилось шлиховое опробование, описание кернового материала.

Структурно-геоморфологический метод изучения новейших структур [11]. Метод заключается в анализе особенностей рельефа по топографическим картам для выделения новейших структур. Их подтверждение и уточнение требует построения геоморфологических и геологогеоморфологических профилей. Профили проводились по водоразделам как вкрест основных неотектонических структур, так и вдоль их простирания. Геолого-геоморфологические профили дают возможность выделить новейшие поднятия и прогибы, определить более точное положение уступов и выровненных поверхностей, увидеть характерные черты их морфологии, подчеркнуть возможные деформации или другие особенности их строения. Анализ геологических данных позволяет установить состав и возраст горных пород, на которых были выработаны ступени рельефа, их залегание, чтобы более точно проследить степень унаследованности древних структур на новейшем этапе.

$3 D$ геологическое моделирование. Для установления взаимосвязи глубинных и новейших структур применено 3D геологическое моделирование. На основе программного обеспечения ArcGis, Global Mapper оцифровывались геологические, топографические карты, тектонические схемы. В дальнейшем были созданы базы данных в формате ASCII, Elevation data, Grid. После этого полученные данные загружались в программное обеспечение RMS, в котором создается рабочая среда для моделирования. Параметры модели нашей среды - ширина «х», глубина «у», высота «Z»; система привязки координат - проекция Гаусса-Крюгера на основе датума WGS84. Далее производилась загрузка файлов ASCII, Elevation data и Grid, которые мы переработали в 3D модель.

Реконструкиия неотектонического напряженного состояния. Для проведения геодинамического анализа территории исследования был применен структурно-геоморфологический метод (СГМ) реконструкции сдвиговых напряжений [15]. Он основан на повсеместном развитии в осадочном чехле платформ крутопадающих разломов, требующих горизональной ориентации осей сжатия и растяжения. Ориентация оперяющих разрывов или вторичных нарушений в зонах динамического влияния сдвигов как по полевым данным, так и по данным моделирования, обобщена М.В. Гзовским [1] и представлена на (рис. 1). Этот рисунок используется в СГМ и назван нами «палеткой Гзовского». В каждом варианте выделяются две системы сопряженных сколов и система отрывов, параллельная оси сжатия. Технология метода заключается в дешифрировании всех мелких прямолинейных элементов рельефа, названных мегатрещинами, вблизи предполагаемого или действительного разрывного нарушения. Для дешифрирования используются топографические карты, космические и аэрофотоснимки, масштаб которых зависит от конкретных целей. 


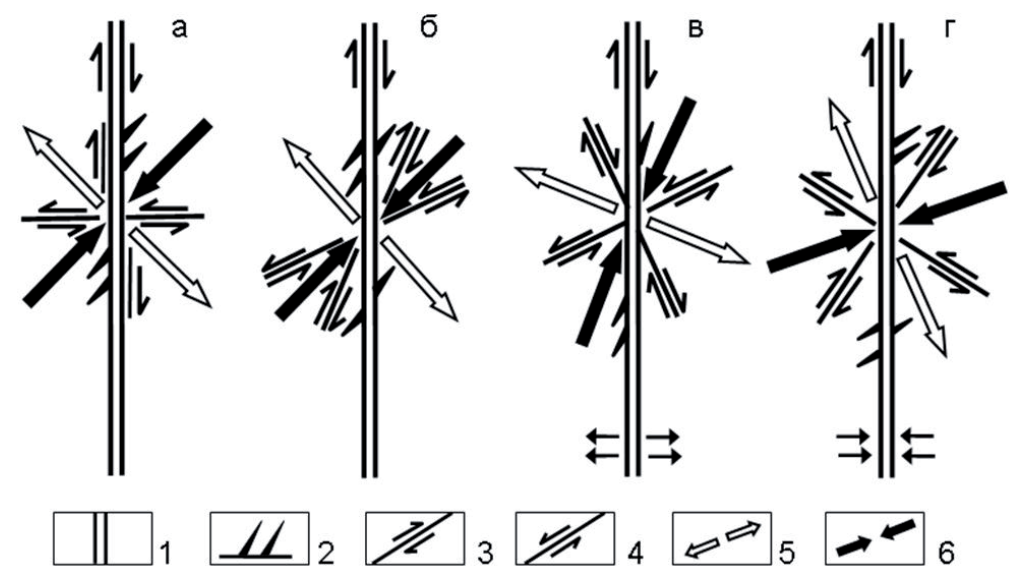

Рис. 1. Парагенезис оперяющих трещин в зоне сдвига [1]. «Палетка Гзовского». Варианты напряженного состояния при углах скалывания $45^{\circ}$ (a), $<45^{\circ}$ (б), обстановки дополнительного растяжения (в) и сжатия (г). 1 - разлом; 2 - трещина отрыва; 3, 4 - сколы с правой (3) и левой (4) сдвиговой кинематикой; 5, 6 - ориентация осей растяжения (5) и сжатия (6) в горизонтальной плоскости.

\section{Новейшая структура и геодинамика}

На изучаемой территории выделяется ряд неотектонических структур, таких как, Оленекское поднятие (или свод).

В новейшее время произошла перестройка структурного плана. Древний Оленекский свод после продолжительного платформенного этапа, прерываемого вспышками магматизма $[6 ; 7 ; 8 ; 9 ; 10]$, был унаследован новейшим одноименным поднятием, а на месте древних прогибов образовались на севере Келимярский прогиб, на востоке - поднятие кряжа Чекановского, на юге - Кютингдинский прогиб, на северо-востоке - Бурский прогиб. К югу и юго-востоку от Оленекского поднятия на неотектоническом этапе сформировались субмеридиональные поднятия, последовательно с запада и с востока понижающиеся к Ленскому прогибу. «Восточные» структуры унаследованно развиваются над западным склоном древнего Предверхоянского прогиба, в то время как центральная и восточная части древнего прогиба втянуты в поднятие Верхоянского хребта. В новейшей тектонической структуре территории Лено-Оленекского междуречья отчетливо выделяются две разноплановые области - северная и южная.

Анализ полей напряжения на исследуемой территории подчеркивают в области Оленекского поднятия радиальный рост и развитие прогибов в окаймлении самого поднятия, что подтверждает его развитие по настоящие дни. Кроме этого общее положение локальных мелких брахиморфных поднятий внутри Оленексого выявляют активное расширение последнего в северо-западном направлении. В области южного обрамления Оленекского поднятия «подсвечиваются» широтные ориентировки сжатия, что в совокупности дает объяснение и взаимосвязь между меридиональными куэстовыми поднятиями на западе, активно-растущего Верхоянского хребта на востоке и крупной Приленской впадины.

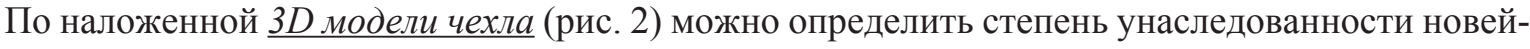
ших структур от древних. Унаследованными структурами, развивающимися над крупными древними Оленекским и Мунским сводами являются Оленекское и Куойско-Суханское поднятия, над древними Хастахским и Кютингдинским грабенами - Бурский и Кютингдинский прогибы, новейший Ленский прогиб развит над периферией мезозойского Предверхоянского прогиба. К инверсионным структурам относятся Кряж Чекановского и ступени-поднятия Верхоянья - Восточно-Приленское, Джарджан-Натарское, Собопольское. Они развиты над древним Предверхоянским прогибом. Такие структуры, как Мунско-Сюнгюдинское поднятие, Келимярская впадина, не имеют прямой взаимосвязи с древнейшими структурами, так как их эволюция связана с развитием смежных структур. Например, для Келимярской впадины - это воздействие Оленекского поднятия с запада и Кряжа Чекановского с востока. Кроме того, асимметричная форма новейших структур юга исследуемой тер- 
ритории свидетельствует о возможном давлении со стороны активно развивающегося Верхоянского хребта. Куэстовый рельеф характерен и для Кряжа Чекановского.

Резюмируя все выше сказанное, можно сделать следующие выводы: структурногеоморфологический метод анализа вторичных нарушений, базирующийся на принципах тектонофизического моделирования [15], показал, что формирование большинства разломов, независимо от их простирания и ранга, происходит преимущественно в обстановке транспрессии. Обстановки транстенсии крайне редки и характерны лишь для новейших отрицательных структур. Анализ морфологии новейших структур в комплексе с тектонофизическим методом позволил разделить территорию Лено-Оленекского междуречья на несколько областей с разными геодинамическими обстановками формирования структур. Основными источниками, которые влияют на особенности структурного плана территории исследования, являются новейшие активно развивающиеся Оленекское поднятие и Верхоянский Хребет. На основании детального анализа линеаментов, проведенного в пределах Оленекского поднятия, установлены направления возможного сжатия, что соответствует результатам тектонофизического анализа.

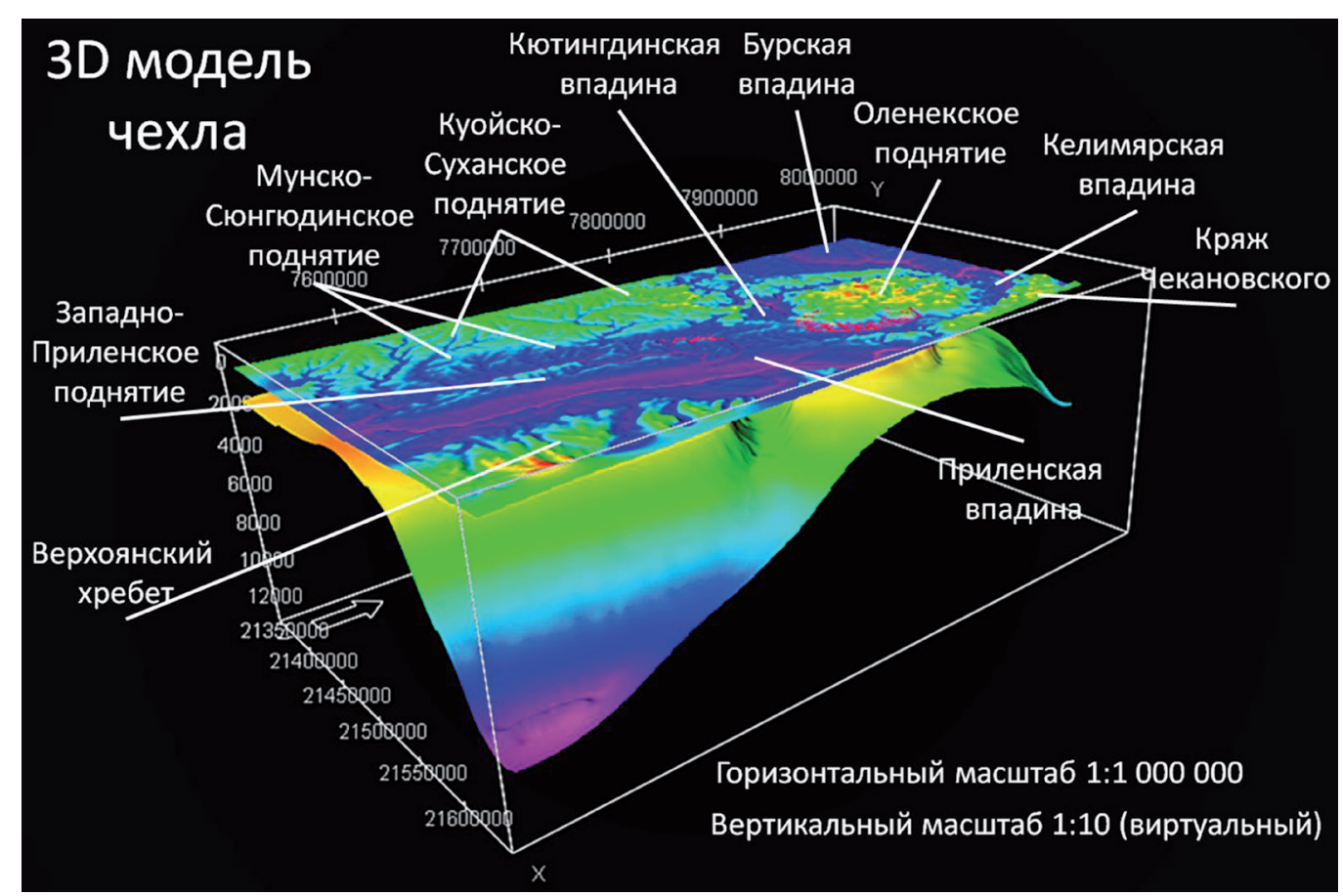

Рис. 2. 3D модель чехла.

\section{Литература}

1. Гзовский М.В. Основы тектонофизики / Гзовский М.В. М.: Наука. 1975. 536 с.

2. Граханов С.А. Рэтские россыпи алмазов 2010.

3. Граханов С.А. Особенности формирования и закономерности размещения россыпей алмазов северо-востока Сибирской платформы Автореферат дисс. на соиск. уч. степени доктора геол.-минер. н. Якутск, 2007.

4. Грачев А.Ф. Основные Проблемы Новейшей Тектоники И Геодинамики Северной Евразии // Физика Земли. № 12. Москва. 1996. С. 5-36.

5. Геологическая карта ССCР масштаба 1:200000. Серия Анабарская. Лист R-51-IX, X. Объяснительная записка. Составитель Н.И. Гогина. М.: Недра. 1975. 89 с.

6. Геологическая карта СCCP масштаба 1:200000. Нижне-Ленская серия. Лист R-51-V, VI. Объяснительная записка. Составители Д.С. Яшин, Д.А. Вольнов. М.: Недра, 1965. 49 с.

7. Геологическая карта дочетвертичных образований. Масштаб 1:1 000 000. Серия Джарджан. Лист R-51. Составитель В.С. Гриненко, Л.А. Юганова, А.М. Трущелев. С-Пб.: ВСЕГЕИ, 2013.

8. Государственная геологическая карта Российской Федерации масштаба 1:1000000. Серия Джарджан. Лист R-51. Объяснительная записка. Составитель В.С. Гриненко, Л.А. Юганова, А.М. Трущелев. С-Пб.: ВСЕГЕИ. 2013. 
9. Государственная геологическая карта СССР масштаба 1:200000. 1960.

10. Карта поверхностей выравнивания и кор выветривания СССР. Масштаб 1:2500000. М.: ВСЕГЕИ. 1972.

11. Макаров В.И. Некоторые проблемы изучения новейшей тектоники платформенных территорий (на примере Русской плиты) // Разведка и охрана недр. 1997. №1. С. 20-26.

12. Объяснительная записка к сдвоенному листу R-51-V, VI Госгеолкарты СССР масштаба 1:200000. 1960.

13. Поляков А.А., Блинова В.Н., Каширцева В.А., Смирнова М.Е., Новые данные о геологическом строении Оленекского месторождения битумов и перспективах нефтегазоносности прилегающей территории // Нефтегазовая геология. Теория и практика. 2011. Т. 6. № 3.

14. Николаев Н.И., Карта новейшей тектоники СССР и сопредельных областей. М.: Мингео СССР. 1979.

15. Сим Л.А. Изучение тектонических напряжений по геологическим индикаторам (методы, результаты, рекомендации). Изв. вузов. геол. и разв. / Сим Л.А. 1991. № 10. С. 3-22.

\section{Фондовые материалы}

16. Галабала Р.О. (отв. исп.). Геологическое строение и полезные ископаемые междуречья Лены и Оленека. Отчет партии № 14 об АФГК масштаба 1 : 50000 на площади листов К-51-19-24, 36, 48; К-52-13, 14, 25, 26, 37-39, проведенном в 1988-1992 гг. М. 1992.

17. Граханов С.А. Отчет о результатах прогнозно-поисковых работ на коренные месторождения алмазов в пределах Оленёкского поднятия (Республика Саха (Якутия)) в 2007-2010, ф. 